\title{
Extensive subarachnoid venous angiomatosis with hydrocephalus in phacomatosis pigmentovascularis
}

Figure Cutaneous findings, head circumference changes, and neuroimages
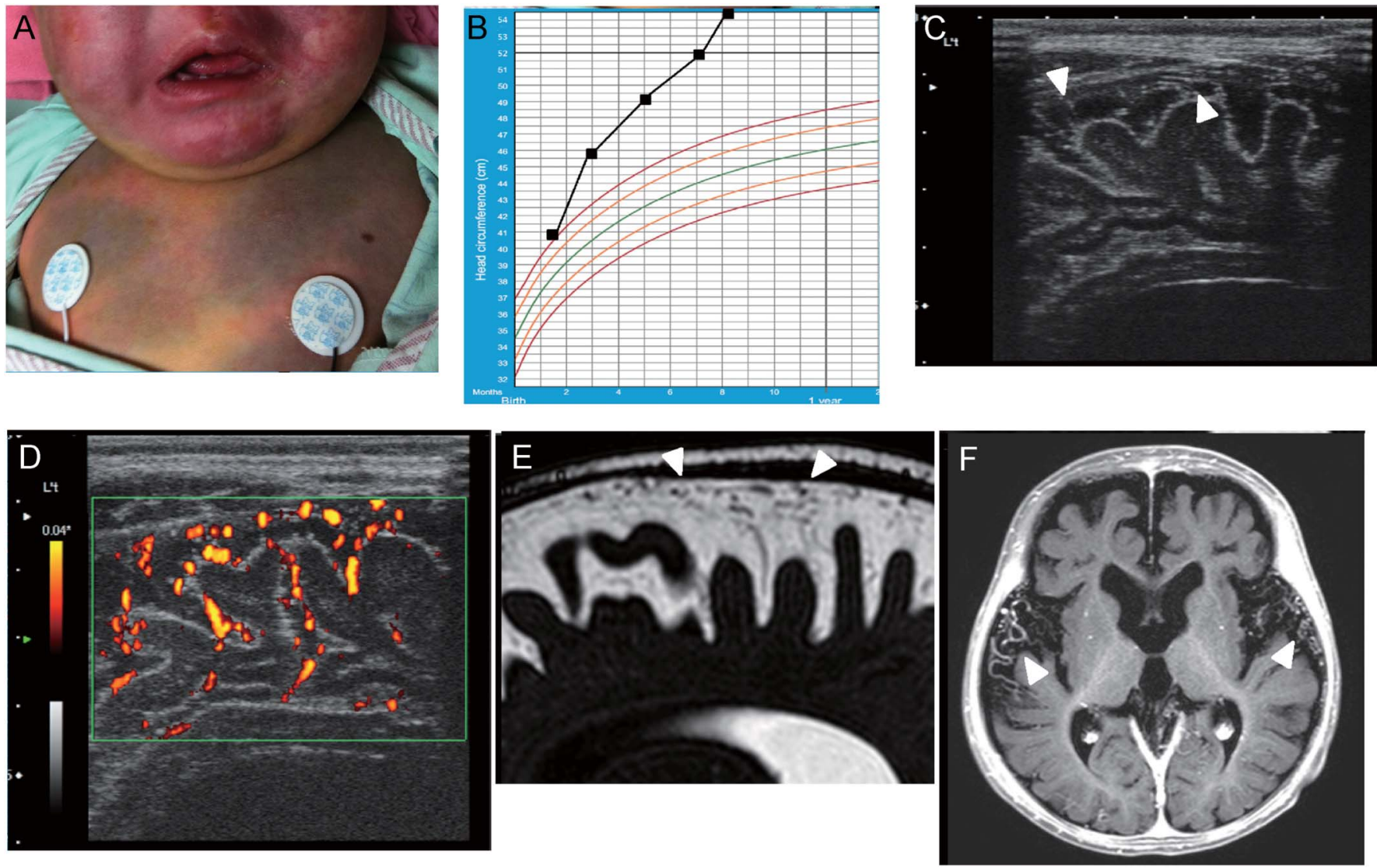

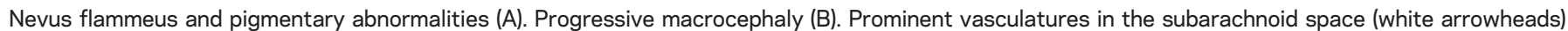

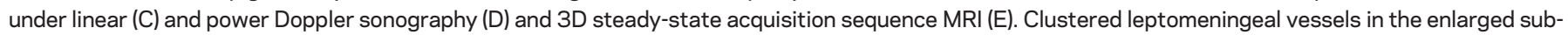
arachnoid space and nonobstructive ventriculomegaly on enhanced T1-weighted image (F).

An 8-month-old boy with cutaneous vascular malformations and dermal melanocytosis (Mongolian spots, figure, A) on the face and trunk was diagnosed with phacomatosis pigmentovascularis type 2. He had normal neurodevelopment, but progressive macrocephaly (figure, B). Linear brain ultrasonography showed extensive venous angiomatosis in the prominent subarachnoid space (figure, $\mathrm{C}$ and D). MRI revealed cortical sulcal widening, prominent leptomeningeal vessels in an enlarged subarachnoid space (figure, $\mathrm{E}$ and $\mathrm{F}$ ), and communicating hydrocephalus (figure, F). Neurologic involvement in phacomatosis pigmentovascularis is uncommon except in Sturge-Weber and Klippel-Trenaunay syndromes. ${ }^{1,2}$ Communicating hydrocephalus due to subarachnoid angiomatosis may be underdiagnosed in phacomatosis pigmentovascularis, and should be considered in cases of progressive macrocephaly.

Li-Wen Chen, MD, Yi-Shan Tsai, MD, Jung-Shun Lee, MD, MS, Yi-Fang Tu, MD, PhD, Chao-Ching Huang, MD

From National Cheng Kung University College of Medicine, Tainan, Taiwan.

Author contributions: All authors participated in the study concept and design and figure acquisitions. The manuscript was drafted by Dr. Chen and Dr. Tsai and revised by Dr. Huang. All the authors made an intellectual contribution to the final manuscript. 
Study funding: No targeted funding reported.

Disclosure: The authors report no disclosures relevant to the manuscript. Go to Neurology.org for full disclosures.

Correspondence to Dr. Huang: huangped@mail.ncku.edu.tw

1. Hall BD, Cadle RG, Morrill-Cornelius SM, Bay CA. Phakomatosis pigmentovascularis: Implications for severity with special reference to Mongolian spots associated with Sturge-Weber and Klippel-Trenaunay syndromes. Am J Med Genet 2007;143A: 3047-3053.

2. Fernández-Guarino M, Boixeda P, de Las Heras E, Aboin S, García-Millán C, Olasolo PJ. Phakomatosis pigmentovascularis: clinical findings in 15 patients and review of the literature. J Am Acad Dermatol 2008;58:88-93.

\section{NeuroImages Are Free at www.neurology.org!}

All Neurology ${ }^{\circledR}$ NeuroImages can now be freely accessed on the Neurology Web site. See them at www.neurology.org, where you can also sign up for journal email alerts and check out other online features, including the Resident \& Fellow section, Neurology: Clinical Practice, and the weekly Neurology Podcasts. 


\section{Neurology}

\section{Extensive subarachnoid venous angiomatosis with hydrocephalus in phacomatosis pigmentovascularis}

Li-Wen Chen, Yi-Shan Tsai, Jung-Shun Lee, et al.

Neurology 2013;81;1020-1021

DOI 10.1212/WNL.0b013e3182a43ba6

This information is current as of September 9, 2013

Updated Information \&

Services

References

Subspecialty Collections

Permissions \& Licensing

Reprints including high resolution figures, can be found at: http://n.neurology.org/content/81/11/1020.full

This article cites 2 articles, 0 of which you can access for free at: http://n.neurology.org/content/81/11/1020.full\#ref-list-1

This article, along with others on similar topics, appears in the following collection(s):

All Clinical Neurology

http://n.neurology.org/cgi/collection/all_clinical_neurology

All Pediatric

http://n.neurology.org/cgi/collection/all_pediatric

MRI

http://n.neurology.org/cgi/collection/mri

Other neurocutaneous disorders

http://n.neurology.org/cgi/collection/other_neurocutaneous_disorders Ultrasound

http://n.neurology.org/cgi/collection/ultrasound

Information about reproducing this article in parts (figures,tables) or in its entirety can be found online at:

http://www.neurology.org/about/about_the_journal\#permissions

Information about ordering reprints can be found online:

http://n.neurology.org/subscribers/advertise

Neurology ${ }^{\circledR}$ is the official journal of the American Academy of Neurology. Published continuously since 1951 , it is now a weekly with 48 issues per year. Copyright @ 2013 American Academy of Neurology. All rights reserved. Print ISSN: 0028-3878. Online ISSN: 1526-632X.

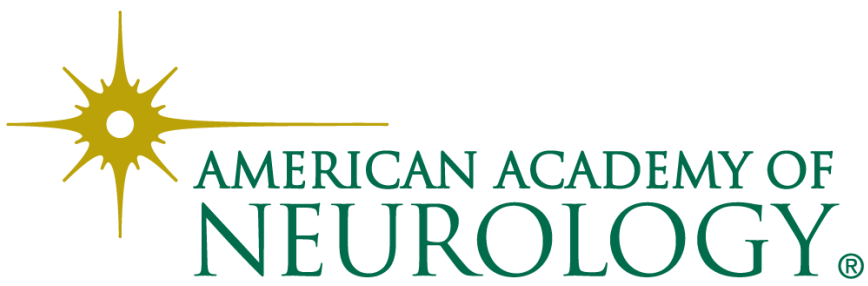

